\title{
Duch Święty dany wierzącym - po co?
}

\section{HENRYK WITCZYK}

Katolicki Uniwersytet Lubelski Jana Pawła II

henwit@kul.pl, ORCID 0000-0003-4451-0697

„Weźmijcie Ducha Świętego!” - tymi słowami zmartwychwstały Jezus przekazuje apostołom w Wieczerniku najważniejszy i największy Dar (por. J 20,21-22). Zewnętrzna manifestacja tego Daru nastąpi w Dniu Pięćdziesiątnicy (Dz 2). Rodzący się Kościół został namaszczony Duchem Świętym na samym początku swej publicznej działalności, adresowanej do wszystkich narodów świata (por. Mt 28,20). Wcześniej takie uroczyste namaszczenie Duchem Świętym dokonało się podczas chrztu udzielanego przez Jana w Jordanie, gdy na Jezusa z Nazaretu, i tylko na Niego, zstąpił oraz pozostawał nad Nim Duch (por. J 1,32-34).

To początkowe i zarazem podstawowe namaszczenie Kościoła Duchem Świętym uobecnia się w sakramentach chrztu i bierzmowania w odniesieniu do każdego chrześcijanina: „Wy natomiast macie namaszczenie od Świętego i wszyscy jesteście napełnieni wiedzą. [...] Co do was, to namaszczenie, które otrzymaliście od Niego, trwa $w$ was i nie potrzebujecie pouczenia od nikogo, ponieważ Jego namaszczenie poucza was o wszystkim. Ono jest prawdziwe i nie jest kłamstwem. Toteż trwajcie w nim tak, jak was nauczyło" (1 J 2,20.27; por. J 7,37-39).

Przez wieki i w odniesieniu do każdego ochrzczonego zmartwychwstały Jezus wypełnia swą obietnicę, dając im Ducha Parakleta i Ducha Prawdy (por. J 14,16.26; 15,26; 16,7.13), który wypełnia swą rolę, wnosząc Bożą Mądrość w ich serca, dusze i sumienia (por. Mdr 7,7.22-30; 1 Kor 12,7-11; Ef 1,17). Ten Duch mówi do Kościoła apostolskiego zagrożonego przez demoniczne siły Zła (por. Ap 2-3) oraz do Kościoła i wraz z Kościołem pielgrzymującym przez wieki pośród wszelkich możliwych przeciwności - aż do skończenia świata (por. Ap 22,17). On działa i zbawia każdego wierzącego, włączając go w misterium męki, śmierci i zmartwychwstania Jezusa (por. Rz 8,1-17; 1 Kor 12,3; Ga 4,6), którego Bóg ustanowił i Panem i Mesjaszem, Sędzią żywych i umarłych (por. Dz 10,42).

Te oraz inne działania Ducha Świętego zostały poddane analizom egzegetyczno-teologicznym w niniejszym numerze Verbum Vitae. Jakkolwiek dotyczą one róż- 
nych tekstów Starego i Nowego Testamentu, a także kilku pism Ojców Kościoła, to jednak tworzą harmonijną całość. Decyduje o niej nieskończone misterium Tego, który stwarza, oświeca, uświęca i ożywia. Zapowiedziany w figurze Mądrości Bożej przenikającej całe stworzenie i całą historię zbawienia, objawia się w pełni w dziejach Jezusa Chrystusa i Jego Kościoła. Inspiruje także współczesne myślenie spekulatywne, kerygmantyczno-katechetyczne i to dotyczące życia duchowego Kościoła naszych czasów, o czym świadczą liczne artykuły w bogatym dziale Ojcowie i życie Kościoła.

Można mieć nadzieję, że tak bogata oferta analiz różnorodnej działalności Ducha Świętego pozwoli zobaczyć szerzej i głębiej całe bogactwo Jego Osoby i zbawczego posłannictwa w Kościele Jezusa Chrystusa i w świecie stworzonym przez Boga. 